\title{
Role Of Habitual Risk Factors On Oral Squamous Cell Carcinoma
}

\author{
Hannan M A ${ }^{1}$, Rahman M A², Hossain $S^{3}$, Rahman Q B
}

Received:10.01.18 Accepted: 18.02 .18

Abstract:

Squamous cell carcinoma is the most common oral malignancy. Betel quid, betel quid with tobacco, smoking, alcohol consumption, mechanical irritation, genetic are the most important risk factors for Oral Squamous Cell Carcinoma (OSCC). The aim of the study was to determine the role of habitual risk factors inOral Squamous Cell Carcinoma.

Materials and Methods: This is a cross-sectional study for the determination of the risk factors of OSCC over 2 years period of January 2011 to December 2012. Department of Oral \& Maxillofacial Surgery, Bangabandhu Sheikh Mujib Medical University, Dhaka, Department of Oral \& Maxillofacial Surgery, Dhaka Dental College Hospital, Dhaka,National Institute of Cancer Research \& Hospital (NICRH), Mohakhali, Dhaka and Health and Hope Hospital, Dhaka from January 2011 to December 2012

Results:250 patients, comprising 44\% male and 56\% female were included in the study. Overall mean age was $55.94 \pm 10.93$ years. The patients of OSCChavemost common habit of betel quid with tobacco 124(49.6\%), then betel quid with tobacco and smoking 49(19.6\%), betel quid with tobacco and Gul 19(7.6\%), only smoking 13(5.2\%), Betel quid without tobacco and smoking 13(5.2\%), betel quid without tobacco 12(5.2\%), betel quid with tobacco and catechu (Khoir) 4(1.6\%), betel quid with tobacco, smoking and gul 3(1.2\%), betel quid without tobacco,smoking and alcohol 2(0.8\%), betel quid without tobacco and gul 2(0.8\%), betel quid without tobacco, smoking and gul $1(0.4 \%)$, betel nut chewing 1(0.4\%), mechanical irritation but no habit 5(2.0\%) and no habitual history 2(0.8\%).

Conclusion: According to this study betel quid, betel quid with tobacco, gul, smoking are the important risk factors in OSCC.

Key words : Habitualrisk factors, Oral Squamous Cell Carcinoma.(OSCC)

1.Dr. Md. Abdul Hannan, BDS,MS (OMS), Assistant Registrar, Department of Oral \& Maxillofacial Surgery, Dhaka Dental College Hospital, Dhaka,Bangladesh.

2. Dr. Mohammad Asifur Rahman, BDS, MS(OMS), Assistant Professor, Department of Oral \& Maxillofacial Surgery, Dhaka Dental College Hospital, Dhaka,Bangladesh.

3. DR. Shakhawat Hossain, BDS,MS(OMS), Assistant Professor, Department of Oral \& Maxillofacial Surgery, Faculty of Dentistry, Bangabandhu Sheikh Mujib Medical University, Dhaka, Bangladesh.

4. DR. Quazi Billur Rahman, MD, PhD, Professor and Chairman,Department of Oral \& Maxillofacial Surgery, Faculty of Dentistry, Bangabandhu Sheikh Mujib Medical University,Dhaka, Bangladesh.

Correspondence : Dr. Md. Abdul Hannan,E mail: abdulhannan33ddc@gmail.com,Cell: 01712064681 


\section{Introduction}

Oral squamous cell carcinoma (OSCC) is the most common malignant epithelial neoplasm affecting the oral cavity. ${ }^{1}$ It is a major global health issue, with half a million new cases diagnosed per year. ${ }^{2}$ In Bangladesh the number of new cancer cases per year is about two lacks of which oral cancer is about $20 \%{ }^{3}$ The etiology of oral squamous cell carcinoma is complex and multifactorial. Chewing tobacco, smoking and alcohol consumption are the most strongly implicated risk factors for the development of oral squamous cell carcinoma. Other risk factors including chewing areca nut, chronic irritation, certain viruses, oral candidiasis, poor oral hygiene, exposure to industrial products, ionizing radiation, age, familial or genetic predisposition. ${ }^{4}$

The association between tobacco smoking and oral squamous cell carcinoma is well established. Oral use of smokeless tobacco is practiced worldwide in many forms. ${ }^{5}$ The developing countries in Southeast Asia and Pacific Rim the habit of tobacco chewing is usually associated with the use of areca nut, which may have a synergistic effect on the development of cancerous and precancerous lesions.

A number of studies have characterized smokeless tobacco as an etiological factor in the development of cancer of the oral cavity and the esophagus. ${ }^{5-6}$ In the West, there are three basic types of smokeless tobacco commonly used in the oral cavitydry air cured tobacco, which is shredded into flakes and treated with flavoring solutions; moist snuff, which consists of air and fire cured dark tobacco that is finely cut and fermented and dry snuff, which is fire-cured and pulverized into powder. All of these products are placed in contact with the oral mucosa, usually between the cheek and gum. Moist snuff and chewing tobacco are used primarily by men, whereas dry snuff is used more often by women. ${ }^{7,8}$

Usually in this sub-continent the betel quid is known as paan which is a package formed from the leaf of the Piper betel plant. Paan is made by adding ingredients including slices of areca nut, slaked lime (calcium hydroxide), tobacco, spices and a variety of other ingredients depending on availability, geographical location, and ceremonial occasion. The package is folded into a triangular quid and chewed, sometimes even swallowed. The slaked lime is used to increase the $\mathrm{pH}$ of the oral cavity, aiding absorption of nicotine by the oral mucosa. ${ }^{9}$

There is an independent effect of paan without tobac$c o$ in the causation of oral cancer. Its findings may be of significance in south Asian communities where paan is used. People with oral sub mucous fibrosis were 19.1 times more likely to develop oral cancer than those without it, after adjusting for other risk factors. People using paan without tobacco were 9.9 times, those using paan with tobacco 8.4 times, more likely to develop oral cancer as compared with nonusers, after adjustment for other covariates. ${ }^{10}$ Oral squamous cell carcinoma has one of the highest recorded incidence in developing countries, comprising $20-30 \%$ of all neoplasms. ${ }^{11}$

Many studies were carried out about the risk factors of OSCC but most of them were done with one or two risk factors. Among them betel quid chewing, tobacco chewing, smoking and alcohol are considered as highest risk factor. In Bangladesh many people are habituated with multiple risk factors of OSCC and many are habituated with single risk factor. At present OSCC as a major health issue of Bangladesh among other malignancy and identification of risk factors for these OSCC affected people is a major time demand. The objectives of this study was to assess the relation of habitual risk factors on oral squamous cell carcinoma, to identify the frequency of oral squamous cell carcinoma in tertiary hospital and its association with multifactorial habitual risk factors. This study was designed to find out the habitual risk factors associated with oral squamous cell carcinoma among Bangladeshi people.

\section{Materials \& Methods}

This is a randomized cross-sectional study.Department of Oral \& Maxillofacial Surgery, Bangabandhu Sheikh Mujib Medical University, Dhaka, Department of Oral \& Maxillofacial Surgery, Dhaka Dental College Hospital, Dhaka,National Institute of Cancer Research \& Hospital (NICRH), Mohakhali, Dhaka and Health and Hope Hospital, Dhaka from January 2011 to December 2012. All the patients who were diagnosed as oral squamous cell carcinoma irrespective of age and sex, fulfilling the basic requirements of inclusion and exclusion criteria were included in this study. Total number of patients were 250 (Two hundred and fifty).

Inclusion criteria washistopathologically diagnosed 
patients with oral squamous cell carcinoma, those who gave consent to be included in the study.

Exclusion criteria waspatientssuffering from another type of malignancy,recurrent oral squamous cell carcinoma patients,Psychotic patient,Patient with inadequate information.

\section{Ethical Consideration}

The research protocol was approved by concerns of the department. The aims and objectives of the study along with its procedure, alternative diagnostic methods, risk and benefit of the study was explained to the patients in easily understandable local language and then informed consent was taken from the patients. It was assured that all information and records would be kept confidential and the procedure would be helpful for both attending surgeon and patients in making decision for management.

\section{Study Procedure}

At first informed written consent was taken from the patients those made the requirements of both inclusion and exclusion criteria. The following a pre-developed standardized questionnaire / history sheet they were interrogated age, sex, habits (tobacco, alcohol consumption, paan, betel, smokeless tobacco, gul), occupation, medical records and familial antecedents of neoplasm. Then following the ideal protocol of examination all the patients were examined who identify the size, site, and duration, fixity with overlying skin or underlying structure and presence of pain. Collected data were posted in data sheet.

Regarding habit of the patients, the risk factors were evaluated individually. For tobacco use regular users with at least $>10$ sticks/day for at least one year was considered as risk factors for betel quid with tobacco at least 7 leaf/day for one year was considered as risk factors. Regarding gul, catechu (khair), those also used at least once in a day at any amount was considered as risk factors. All these data was analyzed with statistical software (SPSS version 16). Frequency and percentage was calculated for categorical variables and mean and standard deviation for continuous variables.

\section{Results And Observations}

Table-I: Age distribution of the patients $(n=250)$

\begin{tabular}{|l|l|l|l|}
\hline $\begin{array}{l}\text { Age (in } \\
\text { years) }\end{array}$ & Frequency & $\begin{array}{l}\text { Percentage } \\
(\%)\end{array}$ & Mean \pm SD \\
\hline 20-30 years & 2 & 0.80 & $27.50 \pm 3.53$ \\
\hline 31-40 years & 21 & 8.4 & $38.14 \pm 2.43$ \\
\hline 41-50 years & 78 & 31.2 & $47.89 \pm 2.36$ \\
\hline 51-60 years & 80 & 32.0 & $57.43 \pm 2.62$ \\
\hline $61-70$ years & 52 & 20.8 & $66.73 \pm 2.72$ \\
\hline $71-80$ years & 14 & 5.6 & $76.21 \pm 2.42$ \\
\hline$>80$ years & 3 & 1.25 & $87.00 \pm 2.64$ \\
\hline Total & 250 & 100.0 & $55.94 \pm 10.93$ \\
\hline Range & $(25-90)$ years & \\
\hline
\end{tabular}

Most of the patients in this study were 6th decade $(32.0 \%)$ and then 5 th decade $(31.2 \%)$ and then 7 th decade (20.8\%), 4th decade (8.4\%) and then above 8th decade (5.6\%) and least 3rd decade $(0.80 \%)$. Mean age of the patients was $55.94 \pm 10.93$ (Table-I).

Fig. 1: Figure shows sex distribution of the patients $(n=250)$
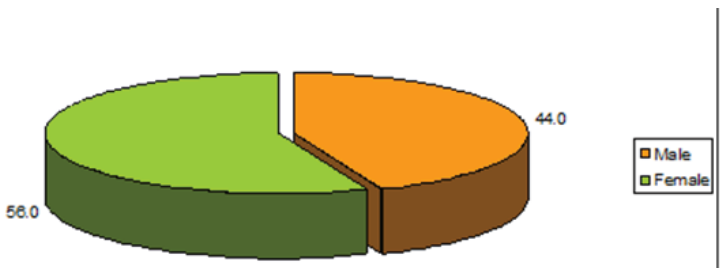

Figure shows female are more affected than male and male:female ratio was $1: 1.27$.

Table-II: Distribution of the patients according to habitual history $(n=250)$

\begin{tabular}{|l|l|l|}
\hline Habitual factor & $\begin{array}{l}\text { No of } \\
\text { patients }\end{array}$ & $\begin{array}{l}\text { Percenta } \\
\text { ge (\%) }\end{array}$ \\
\hline Betel quid with tobacco & 124 & 49.6 \\
\hline Betel quid with tobacco+ Smoking & 49 & 19.6 \\
\hline Betel quid with tobacco+ Gul & 19 & 7.6 \\
\hline Smoking only & 13 & 5.2 \\
\hline Betel quid without tobacco+ Smoking & 13 & 5.2 \\
\hline Betel quid without tobacco & 12 & 4.8 \\
\hline Betel quid with tobacco + Catechu (Khoir) & 4 & 1.6 \\
\hline
\end{tabular}




\begin{tabular}{|l|l|l|}
\hline Betel quid with tobacco+ Smoking +Gul & 3 & 1.2 \\
\hline $\begin{array}{l}\text { Betel quid without tobacco +Smoking + } \\
\text { Alcohol }\end{array}$ & 2 & 0.8 \\
\hline Betel quid without tobacco+ Gul & 2 & 0.8 \\
\hline Betel quid without tobacco+ Smoking + Gul & 1 & 0.4 \\
\hline Betel nut chewing & 1 & 0.4 \\
\hline Mechanical irritation but no habit & 5 & 2.0 \\
\hline No habitual history & 2 & 0.8 \\
\hline Total & 250 & 100.0 \\
\hline
\end{tabular}

Table-II shows the patients of OSCC have the most common habit of betel quid with tobacco 124(49.6\%) and then betel quid with tobacco and smoking $49(19.6 \%)$. Betel quid with tobacco + Gul 19(7.6\%), only smoking $13(5.2 \%)$, Betel quid without tobacco+ Smoking 13(5.2\%), Betel quid without tobacco $12(5.2 \%)$, Betel quid with tobacco + catechu (Khoir) $4(1.6 \%)$, Betel quid with tobacco+ Smoking +Gul $3(1.2 \%)$, Betel quid without tobacco +Smoking + Alcohol 2(0.8\%), Betel quid without tobacco+ Gul $2(0.8 \%)$, Betel quid without tobacco + Smoking + Gul $1(0.4 \%)$, Betel nut chewing $1(0.4 \%)$, Mechanical irritation but no habit $5(2.0 \%)$ and No habitual history $2(0.8 \%)$.

Table-III: Distribution of the patients according to habit of betel quid and other than betel quid $(n=250)$

\begin{tabular}{|l|l|l|}
\hline Habitualfactor & $\begin{array}{l}\text { No of } \\
\text { patients }\end{array}$ & $\begin{array}{l}\text { Percentage } \\
(\%)\end{array}$ \\
\hline Betelquid only & 12 & 4.8 \\
\hline $\begin{array}{l}\text { Betel quid with other habits } \\
\text { (tobacco, smoking, gul, catechu } \\
\text { (khoir), alcoholetc.) }\end{array}$ & 217 & 86.8 \\
\hline Smokingonly no & 5 & 2.0 \\
\hline $\begin{array}{l}\text { Mechanical irritation but nabit } \\
\text { habit }\end{array}$ & 13 & 5.2 \\
\hline Betelnut chewing & 1 & 0.4 \\
\hline No habitualhistory & 2 & 0.8 \\
\hline Total & 250 & 100.0 \\
\hline
\end{tabular}

Table-III shows that the patients of OSCC have the habit of taking betel quid alone 12(4.8\%) and betel quid in association with other habits $217(86.8 \%)$. So, betel quid alone or in association with other habits like tobacco, smoking, gul, catechu (khoir), alcohol etc together was $229(91.6 \%$. The habit of smoking only $13(5.2 \%)$. There was 5 patients who have no significant habitual risk factors but presence of mechanical irritation only. 1 patient also had betel nut chewing habit. There was 2 patients who had neither any habitual risk factors nor any mechanical irritation. Table-IV: Distribution of the patients with betel quid by duration (years) $(n=229)$

\begin{tabular}{|l|l|l|}
\hline Duration (years) & No of patients & $\begin{array}{l}\text { Percentage } \\
(\%)\end{array}$ \\
\hline$\leq 10$ & 20 & 8.73 \\
\hline $11-20$ & 47 & 20.52 \\
\hline $21-30$ & 64 & 27.95 \\
\hline $31-40$ & 62 & 27.07 \\
\hline$>40$ & 36 & 15.72 \\
\hline Total & 229 & 100.0 \\
\hline Mean \pm SD & $27.34 \pm 12.65$ & \\
\hline
\end{tabular}

The majority $126(55.02 \%)$ of the patients of OSCC duration of habits was 21-40 years and then $47(20.52 \%)$ of the patients duration of habits was 11 20 years. $36(15.7 \%)$ duration of habit $>40$ years and least $20(8.73 \%)$ patients were duration of habit $<10$ years (Table-IV).

Table-V: Distribution of the patients according to habit by quantity (per day) $(n=243)$

\begin{tabular}{|c|c|c|c|c|c|}
\hline \multirow[t]{2}{*}{ Habit } & \multicolumn{4}{|c|}{$\begin{array}{l}\text { Patient's distribution (No. \%) } \\
\text { according to quantity /day }\end{array}$} & \multirow[t]{2}{*}{ Total } \\
\hline & <10 & $10-20$ & $21-30$ & $>30$ & \\
\hline $\begin{array}{|lll|}\begin{array}{l}\text { Betel } \\
\text { tobacco }\end{array} & \text { quid with } \\
\end{array}$ & $7(5.6 \%)$ & $\begin{array}{l}26(21.0 \\
\%)\end{array}$ & $\begin{array}{l}32(25.8 \\
\%)\end{array}$ & $59(47.6 \%$ & $\begin{array}{l}124(100.0 \\
\%)\end{array}$ \\
\hline \begin{tabular}{|l} 
Betel $\quad$ quid with \\
tobacco+
\end{tabular} & $4(8.2 \%)$ & $\begin{array}{l}21(42.9 \\
\%)\end{array}$ & $\begin{array}{l}12(24.5 \\
\%)\end{array}$ & $12(24.5 \%$ & $\begin{array}{l}49(100.0 \\
\%)\end{array}$ \\
\hline $\begin{array}{|lr|}\text { Betel } \quad \text { quid with } \\
\text { tobacco+ Gul }\end{array}$ & $3(15.8 \%)$ & $7(36.8 \%$ & $7(36.8 \%$ & $2(10.5 \%)$ & $\begin{array}{l}19(100.0 \\
\%)\end{array}$ \\
\hline Only smoking & 0 & $2(15.4 \%$ & $3(23.1 \%$ & $8(61.5 \%)$ & $\begin{array}{l}13(100.0 \\
\%)\end{array}$ \\
\hline $\begin{array}{l}\text { Betel quid without } \\
\text { tobacco+ Smoking }\end{array}$ & $3(23.1 \%)$ & $4(30.8 \%$ & $6(46.2 \%$ & 0 & $\begin{array}{l}13(100.0 \\
\%)\end{array}$ \\
\hline $\begin{array}{l}\text { Betel quid without } \\
\text { tobacco }\end{array}$ & $1(8.3 \%)$ & $2(16.7 \%$ & $5(41.7 \%$ & $4(33.3 \%)$ & $\begin{array}{l}12(100.0 \\
\%)\end{array}$ \\
\hline $\begin{array}{|lrr|}\text { Betel } & \text { quid } & \text { with } \\
\text { tobacco+ } & \text { Catechu } \\
\text { (Khoir) } & & \end{array}$ & & $1(25.0 \%$ & $3(75.0 \%$ & 0 & $4(100.0 \%$ \\
\hline
\end{tabular}




\begin{tabular}{|l|l|l|l|l|l|}
\hline $\begin{array}{l}\text { Betel quid with } \\
\text { tobacco+ } \\
\text { Smoking+Gul }\end{array}$ & $2(66.7 \%)$ & $1(33.3 \%$ & 0 & 0 & $3(100.0 \%$ \\
\hline $\begin{array}{l}\text { Betel quid without } \\
\text { tobacco+Smoking } \\
\text { Alcohol }\end{array}$ & 0 & $\begin{array}{l}2(100.0 \\
\%)\end{array}$ & 0 & 0 & $2(100.0 \%$ \\
\hline $\begin{array}{l}\text { Betel quid without } \\
\text { tobacco+Gul }\end{array}$ & $1(50.0 \%)$ & $1(50.0 \%$ & 0 & 0 & $2(100.0 \%$ \\
\hline $\begin{array}{l}\text { Betel quid without } \\
\text { tobacco+Smoking }+ \\
\text { Gul }\end{array}$ & $\begin{array}{l}1(100.0 \\
\%)\end{array}$ & 0 & 0 & 0 & $1(100.0 \%$ \\
\hline Betel nut chewing & 0 & 0 & 0 & $1(100.0 \%$ & $1(100.0 \%$ \\
\hline Total & 22 & 67 & 68 & 86 & 243 \\
\hline
\end{tabular}

Table-V shows, the patients of OSCC with the habit of Betel quid with tobacco 59(47.6\%) frequency per day more $>30,32(25.8 \%)$ frequency per day 21-30. $26(21.0 \%)$ frequency per day $10-20,7(5.6 \%)$ frequency per day $<10$. With the habit of betel quid with tobacco+ Smoking 21(42.9\%) frequency per day $10-20,12(24.5 \%)$ frequency per day $21-30$ or $>30$, $3(15.8 \%)$ frequency per day $<10$. With the habit of betel quid with tobacco+ Gul 7(36.8\%) frequency per day $10-20$ or $21-30,3(15.8 \%)$ frequency per day $<10$, $2(10.5 \%)$ frequency per day $>30$. With habit of only smoking $8(61.5 \%)$ frequency per day $>30,3(23.1 \%)$ frequency per day 21-30, 2(15.4\%) frequency per day 10-20. With the habit of betel quid without tobacco+ Smoking 6(46.2\%) frequency per day 21-30, $4(30.8 \%)$ frequency per day $10-20,3(23.1 \%)$ frequency per day $<10$. With the habit of betel quid without tobacco $5(41.7 \%)$ frequency per day $21-30$, $4(33.3 \%)$ frequency per day $>30,1(8.3 \%)$ frequency per day $<10$. With the habit of betel quid with tobacco+ Catechu (Khoir) 3(75.0\%) frequency per day 21 $30,1(25.0 \%)$ frequency per day $10-20$. With the habit of betel quid with tobacco+ Smoking+Gul $2(66.7 \%)$ frequency per day $<10,1(33.33 \%)$ frequency per day 10-20. With the habit of betel quid without tobacco+Smoking + Alcohol $2(100.0 \%)$ frequency per day $10-20$. With the habit of betel quid without tobacco+Gul $1(50.0 \%)$ frequency per day $<10$ or $10-20$. With the habit of betel quid without tobacco+Smoking + Gul 1(100.0\%) frequency per day $<10$ and with the habit of betel nut chewing $1(100.0 \%)$ frequency per day $>30$.
Table-VI: Habitual distribution according to sex by quantity (per day) $(n=243)$

\begin{tabular}{|c|c|c|c|c|c|c|}
\hline \multirow{3}{*}{ Habit } & \multicolumn{4}{|c|}{ Sex } & \multirow{2}{*}{\multicolumn{2}{|c|}{ Total }} \\
\hline & \multicolumn{2}{|c|}{ Male } & \multicolumn{2}{|c|}{ Female } & & \\
\hline & No & $\%$ & No & $\%$ & No & $\%$ \\
\hline Betel quid with tobacco & 26 & $\begin{array}{l}10.70 \\
\%\end{array}$ & 98 & $\begin{array}{l}40.3 \\
\%\end{array}$ & 124 & $\begin{array}{l}51.03 \\
\%\end{array}$ \\
\hline $\begin{array}{l}\text { Betel quid with tobacco+ } \\
\text { Smoking }\end{array}$ & 46 & $\begin{array}{l}18.93 \\
\%\end{array}$ & 3 & 1.23 & 49 & 20.16 \\
\hline Betel quid with tobacco+ Gul & 0 & 0 & 19 & 7.82 & 19 & $7.82 \%$ \\
\hline Only smoking & 13 & $5.35 \%$ & 0 & 0.00 & 13 & $5.35 \%$ \\
\hline $\begin{array}{l}\text { Betel quid without tobacco+ } \\
\text { Smoking }\end{array}$ & 11 & $4.53 \%$ & 2 & 0.82 & 13 & $5.35 \%$ \\
\hline Betel quid without tobacco & 3 & $1.23 \%$ & 9 & 3.70 & 12 & $4.94 \%$ \\
\hline $\begin{array}{lll}\text { Betel } & \text { quid with } & \text { tobacco+ } \\
\text { Catechu } & \text { (Khoir) } & \end{array}$ & 2 & $0.82 \%$ & 2 & 0.82 & 4 & $1.65 \%$ \\
\hline $\begin{array}{l}\text { Betel quid with tobacco+ } \\
\text { Smoking+Gul }\end{array}$ & 3 & $1.23 \%$ & 0 & 0.00 & 3 & $1.23 \%$ \\
\hline $\begin{array}{l}\text { Betel quid } \quad \text { without } \\
\text { tobacco+Smoking } \quad+\text { Alcohol }\end{array}$ & 2 & $0.82 \%$ & 0 & 0.00 & 2 & $0.82 \%$ \\
\hline $\begin{array}{ll}\text { Betel quid without } \\
\text { tobacco+Gul }\end{array}$ & 2 & $0.82 \%$ & 0 & 0.00 & 2 & $0.82 \%$ \\
\hline $\begin{array}{l}\text { Betel quid } \quad \text { without } \\
\text { tobacco+Smoking }+ \text { Gul }\end{array}$ & 1 & $0.41 \%$ & 0 & 0.00 & 1 & $0.41 \%$ \\
\hline Betel nut chewing & 0 & 0 & 1 & 0.41 & 1 & $0.41 \%$ \\
\hline
\end{tabular}

Table-VI shows, the patients of OSCC with the habit of Betel quid with tobacco $26(10.70 \%)$ male and $98(40.3 \%)$ female, betel quid with tobacco and smoking $46(18.93 \%)$ male and $3(1.23 \%)$ female. Only smoking $13(5.35 \%)$ male and no female.

\section{Discussion}

Oral cancer is a major and growing worldwide problem. Its incidence, etiology and natural history vary considerably in different population groups. Variation in incidence is related to exposure to known etiological factors such as tobacco and betel nut chewing, smoking and alcohol consumption. ${ }^{12}$

In Bangladesh where betel quid chewing with tobacco is common practice among the people and many people have betel quid chewing with tobacco and smoking habit. Certainly the major risk factors of oral squamous cell carcinoma different from those of 
western world.

The present study showed (Table-II) that as a single factor betel quid chewing with tobacco is a major risk factors of oral squamous cell carcinoma in Bangladesh, but it is not possible find out which one is the main contributory factor to develop OSCC. In the present series of 250 patients, 124(49.6\%) were habituated with betel quid with tobacco and 49(19.6\%) were habituated with betel quid with tobacco plus smoking. A study in Southern India smoking and betel quid with tobacco were major independent risk factors of OSC..$^{13}$ Tarin showed that in Bangladesh $75.6 \%$ were habituated with betel quid chewing with tobacco. ${ }^{14}$

In the presented study (Table-III) showed that betel quid alone or in association with other habits \{tobacco, smoking, gul, catechu (khoir), alcohol etc together was $229(91.6 \%)$ which supported by epidemiological study of Chiba done in this subcontinent which reported betel chewing is the main etiological factor of OSCC in India, Pakistan\& Srilanka. ${ }^{11}$ The patients of OSCC with the habit of Betel quid with tobacco $26(10.70 \%)$ male and $98(40.3 \%)$ female, betel quid with tobacco and smoking 46(18.93\%) male and $3(1.23 \%)$ female. Only smoking $13(5.35 \%)$ male and no female (Table-VI).

But it is completely different from the western would study which estimated the percentage of oral cancers attributable to cigarette smoking have been quite consistent, generally ranging from $75 \%$ to $90 \% .{ }^{15}$ Only two patients of the presented study were found habituated with alcohol consumption which completely differs from the western world, which showed most patients of OSCC drink alcohol. This difference of habit may be due to social and religious barrier. The study of Winn found rate of alcohol consumption as high as $94 \%$ in men and $82 \%$ in woman. ${ }^{16}$ Another study showed that total alcohol intake was significantly associated with risk of OSCC. Heavy alcohol drinker (25 or more $\mathrm{Oz} /$ month) had a relative risk compared with non-drinkers.

An effect of alcoholic beverages was found in subjects with an averages daily consumption of 120 or more grams of alcohol, with a higher risk in beer drinkers. Among heavy consumers of alcohol and tobacco, risk of oral cancer was very high. Merletti showed a positive association between oral cancer and low educational level, after adjustments of alcohol and tobacco was found. ${ }^{17}$ But a study carried out in our country showed similar result to this study. ${ }^{14}$ In this study most common site was buccal mucosa $38.8 \%$ with the habit of betel quid with tobacco and 2nd habit was betel quid with tobacco and smoking (14\%). A study showed that more common site was buccal mucosa. ${ }^{18}$ Another study also showed that the most common site of OSCC was the buccal mucosa. ${ }^{10}$ With the habit of smoking the common sites was buccal mucosa $3.2 \%$ and then tongue about $1.6 \%$. In this study only one patient $(0.4 \%)$ was habituated with betel nut chewing. It is largely different from a study in South African Indian which showed 23\% were habituated with betel nut chewing. ${ }^{18}$

Most of the patients in this study were (TNM staging) stage III 197(78.8\%) and then stage IV 35 (14.0\%), then stage II $15(6.0 \%)$ and least stage I 3 (1.2\%) patients.

In this study age distribution was very widely, from 2nd to 8th and more of the 8th decade of life but most commonly found in 5th\& 6th decade. Mean age of OSCC in this study $55.94 \pm 10.93$ years. This result is similar to studies carried out in our country which reported the incidence of OSCC was more in 6th decade. ${ }^{14}$ But different from western study which reported the incidence of OSCC in higher age group, which was in 7 th decade. ${ }^{19}$ In this study the lowest age was 25 years, only 1 patient who was habituated with betel nut chewing for 3 to 4 years. She was first affected from oral sub mucus fibrosis, which turned into oral squamous cell carcinoma.

In this study female was more affected than male. Male: female ratio was $1: 1.27$. It is more or less similar to a study in South African Indian where male female ratio was 1:1.6 and study of Park et al. showed male female ratio was 2:1 which was different from the present study. ${ }^{18,20}$

\section{Conclusion}

According to this study, betel quid alone or in association with otherhabits like tobacco, smoking, gul, catechu (khoir), alcohol were observed the main risk factors, among them betel quid with tobacco was observed as the most significant risk factors in this study. Oral squamous cell carcinoma has a multifactorial risk factors such as betel quid, betel quid with tobacco, gul, smoking, alcohol etc. It depends on frequency and duration of the risk factors. Overall a 
large scale study with more information from conscious people can be done for better analysis and result.

For accurate information from the OSCC patients, data should be collected from literate person and overcome social and religious problem comparison to random sampling.

\section{References}

1. Markopoulos AK, Current aspects on oral squamous cell carcinoma 2012. The open dentistry Journal, 6:126-130.

2. Pande $P$ et al 2002. Prognostic factors in betel and tobacco related oral cancer. Oral Oncol, 38: 491-9.

3. Shaheed I, Hossain A, Molla MR, 1995. Histological and causative factor of oral cancer in Bangladesh. Oral Oncology, Applied. Proceedings of 4th international congress on oral cancer. Ogaki City, Japan. 27-30.

4. Binnie WH. Rankin KV, Mackenzie IC 1983. Etiology of oral squamous cell carcinoma. J Oral Pathol, 12: 11-29.

5. Idris AM et al 1998. The Swedish sinus and the Sudanese toombak: are they different? Oral Oncol, 34:558-66.

6. Agency for Research on Cancer. Tobacco habits other than smoking; betel-quid and areca-nut chewing; some related nitro-samines. International Agency for Research on Cancer Tobacco. Lyon: IARC monographs on the evaluation of carcinomgenic risks to humans, 1985.

7. Wahlberg IRT 1999. Smokeless tobacco. In: Davis DL NM, editor. Tobacco: production, chemistry and technology. Oxford: Black-well Science: 452-460.

8. Rogozinski J 1990. Smokeless tobacco in the western world. New York: Praeger Publishers: 42-44.

9. Goldenberg D et al 2000. Habitual risk factors for head and neck cancer. American Academy of Otolaryngolo- gyHead and Neck Surgery Foundation, 02: 35.

10. Merchant A et al. 2000. Paan without tobacco: an independent risk factors for oral cancer, In J Cancer, 86: 128-131.

11. Chiba I, Muthumala M, Yamazaki Y, Zaman AU, Tadashi I, Amemiya A et al. 1998. Characteristics of mutatons in the p53 gene of oral squamous cell carcinomas associated with betel quid chewing in Sri Lanka. Int. J. Cancer, 77: 839-42. 12. Ankathil R, Mathew A, Joesph F, Nair MK 1996. Is oral cancer susceptibility inherited? Report of rive oral cancer families. Oral Oncol Eur J Cancer, 32B: 63-7. 13.Sankaranarayanan $R$, et al. 1989. A case control investigation of cancer of the oral tongue and the floor of the mouth in Southern India. Int. J. Cancer, 44: 617-621. 14.Tarin R, 2000. Study of aetiological factors of oral carcinoma and its Relationship with malnutrition. B J Oral Health, 6: 29-34.

15. Shopland DR, Eyre HJ, Pechacek TF, 1991. Smoking-attributable cancer mortality in 1991: is lung cancer now the leading cause of death among smokers in the United States? J Natl Cancer Inst. 83: 1142-8.

16. Winn DM, 1995. Diet and nutrition in the etiology of oral cancer. Am J Clin Nutr, 61: 437s-45S.

17. Merletti $F$ et al. 1989. Role of tobacco and alcoholic beverages in the etiology of cancer of the oral cavity/oropharynx in Torino, Italy. Cancer Research, 49: 4919-24.

18. Van Wyk CW, Stander I, Pandaychee, A, Groblerrable AF 1993. The areca nut chewing habit and oral squamous cell carcinoma in South African Indians. S Afr Med J, 83: 425-429.

19. Henk JM, Langdon JD, 1985. Malignant tumors of oral cavity. First publication. 12:2-8.

20. Park Kohn WG and Malvitz DM, 1998. Preventing and controlling oral and pharyngeal cancer recommendations from a national strategic planning conference. Morbidity and Mortality Weekly Report, 47: 1-12. 